Artikel Penelitian

\title{
Efektivitas Pelatihan Kecakapan Hidup Menggunakan Modul Pengelolaan Emosi pada Remaja Perempuan dengan Lupus Eritematosus Sistemik
}

\author{
Safira A. Tjandrasari, ${ }^{1}$ Fransiska Kaligis, ${ }^{1 *}$ Tjhin Wiguna, ${ }^{1}$ Raden I. Ismail, ${ }^{1}$ \\ Dina Muktiarti²
}

\author{
1Departemen Psikiatri, 'Departemen IImu Kesehatan Anak \\ Fakultas Kedokteran Universitas Indonesia, Jakarta
}

\author{
Penulis korespondensi: kaligisfransiska@gmail.com \\ Diterima 28 November 2020; Disetujui 19 Juli 2021 \\ https://doi.org/10.23886/ejki.9.13.80
}

\begin{abstract}
Abstrak
Lupus eritematosus sistemik (LES) merupakan penyakit kronik yang dapat menyebabkan masalah emosi pada remaja, khususnya perempuan sehingga fokus perawatan pada remaja dengan LES adalah mengatasi gangguan yang dialami secara keseluruhan. Studi ini bertujuan untuk mengetahui masalah emosi pada remaja perempuan dengan LES dan efektivitas pelatihan kecakapan hidup-modul pengelolaan emosi (PKH-MPE) dalam mengatasi masalah emosi. Studi ini menggunakan desain uji klinis teracak dalam 2 grup di RSUPN dr. Cipto Mangungkusumo pada bulan Januari hingga Desember 2019. Subjek adalah 30 remaja perempuan dengan LES yang sudah mendapat terapi dan memiliki skor Systemic Lupus Erythematosus Disease Activity Index (SLEDAI) 0-5. Masalah emosi dinilai dengan Strength and Difficulties Questionnaire (SDQ) pada awal dan 4 minggu pasca perlakuan. Sebanyak 6/30 remaja perempuan memiliki nilai SDQ abnormal pada awal studi. PKH-MPE efektif menurunkan masalah emosi pada kelompok perlakuan dibandingkan kontrol (uji Wilcoxon, $p=0,002)$. Pada kelompok perlakuan terdapat perbaikan total skor SDQ $(p=0,001)$, masalah emosi $(p=0,002)$, masalah perilaku $(p=0,027)$ dan perilaku hiperaktif $(p=0,040)$ dibandingkan awal studi. PKH-MPE secara bermakna mengurangi keluhan nyeri, kecemasan dan perasaan gugup pada kelompok perlakuan. Disimpulkan PKH-MPE efektif memperbaiki masalah emosi pada remaja perempuan dengan LES, terutama keluhan nyeri, cemas, dan perasaan gugup.

Kata kunci: Iupus, penyakit kronis, masalah emosi, pelatihan kecakapan hidup, SDQ.
\end{abstract}

\section{Effectiveness of Life SkillsTraining-Emotional Management Module in Female Adolescent with Systemic Lupus Erythematosus}

\begin{abstract}
Systemic lupus erythematosus (SLE) is a chronic disease that can cause emotional problems in adolescents, predominantly female thus, the focus of care in adolescents with SLE is to treat the patients holistic. The study aims to assess the emotional problems in female adolescents with SLE and the effect of life skills training-emotional management module in female adolescents with SLE. This study is a randomized clinical trial with no blinding which located in Cipto Mangunkusumo Hospital Jakarta. Thirty female adolescents with treated SLE and had Systemic Lupus Erythematosus Disease Activity Index (SLEDAI) score 0-5 were included. Emotional problems were assessed at the beginning of the study and four weeks after intervention. It was found that there were 6/30 subjects with abnormal SDQ at the beginning of the study. Life skills training was found effective in treating emotional problems, compared to control with (Wilcoxon test, $p=0.002$ ). Life skill straining was also found effective in improving SDQ score $(p=0.001)$, emotional problem $(p=0.002)$, conduct problems $(p=0.027)$, and hyperactivity $(p=0.040)$ in the intervention group compared to baseline. Life skill straining reduced physical pain, worries, and nervousness in the intervention group. In conclusion, the life skill straining-emotional management module was effective in improving emotional problems in a female adolescent with SLE, especially physical pain, worries, and nervousness.
\end{abstract}

Keywords: SLE, chronic disease, emotional problems, life skills training, SDQ. 


\section{Pendahuluan}

Lupus eritematosus sistemik (LES) adalah penyakit autoimun kronik yang disebabkan oleh hiperaktivitas sistem imun. Penyakit tersebut ditandai dengan ketidakmampuan antibodi untuk membedakan antigen dan sel normal sehingga menyebabkan kerusakan berbagai organ. LES bermanifestasi dalam banyak bentuk di berbagai organ dan dapat mengancam nyawa. Selain itu, LES ditandai dengan kekambuhan yang tidak sepenuhnya dapat diprediksi sehingga menurunkan kualitas hidup penderita. ${ }^{1,2}$

Prevalensi LES adalah 0,3 - 23,2 per 100.000 penduduk $^{3}$ dan terutama terjadi pada usia 16-55 tahun. Walaupun jarang, LES dapat ditemukan pada anak-anak dan geriatri. ${ }^{1}$ Sebanyak 10 $20 \%$ penderita LES adalah remaja, dengan perbandingan perempuan dan laki-laki $7: 1 .{ }^{4}$ LES terjadi pada remaja perempuan setelah pubertas. Kondisi tersebut menyebabkan gangguan fisik, emosi, dan fungsi pada penderita. ${ }^{5}$

Sebanyak $10 \%$ remaja di dunia mengalami penyakit kronik, salah satunya LES. Penyakit kronik berhubungan erat dengan masalah psikososial, termasuk emosi seperti cemas dan depresi. ${ }^{6}$ Selain itu, terdapat hubungan resiprokal antara LES dan masalah kesehatan mental pada remaja. LES dapat menyebabkan masalah mental dan masalah mental memperburuk manifestasi klinis LES. Prevalensi gangguan emosi pada LES, terutama cemas dan gejala depresi adalah $15-64 \%$, jauh lebih tinggi dibandingkan populasi dewasa (9-23\%). Oleh karena itu, penting memahami hubungan gangguan mental dengan LES pada remaja. ${ }^{7}$

Batubara $^{5}$ melaporkan $83 \%$ penderita LES mengalami masalah emosi seperti kemarahan, kesedihan, putus asa, sensitif, kecewa, ketakutan akan isolasi dari lingkungan, takut mendapat perlakuan berbeda, dan hilangnya motivasi. Masalah mental pada remaja dengan LES merupakan interaksi berbagai hal. Perasaan berbeda dari orang lain, cemas dan rasa tidak berdaya dapat muncul karena gejala klinis yang hilang timbul sehingga mengakibatkan remaja tidak dapat melakukan aktivitas sehari-hari tanpa rasa kuatir seperti remaja seusianya. Selain itu, ketidakpahaman lingkungan terhadap penyakit yang diderita menyebabkan pasien mendapatkan perlakuan berbeda atau merasa tidak diterima lingkungannya. Tumpukan masalah tersebut menyebabkan beban mental pada remaja penderita LES. Respons maladaptif terhadap beban mental dapat memengaruhi respons pasien terhadap penyakit termasuk kepatuhan pengobatan. ${ }^{5}$

Tujuan utama pengobatan pada remaja dengan LES adalah mengatasi keluhan fisik. Tata laksana utama adalah farmakoterapi berupa imunosupresan dan steroid bergantung manifestasi klinis. Pendekatan yang lebih komprehensif, termasuk dukungan psikososial pada pasien belum menjadi standar tata laksana pasien. Sementara itu, ketidakpastian penyakit dan beban mental menyebabkan pasien menginginkan terapi untuk memperbaiki gejala di organ serta tata laksana secara holistik. ${ }^{1}$

Saat ini terapi psikososial, termasuk tata laksana oleh ahli kesehatan jiwa, diberikan pada pasien yang menunjukkan gejala klinis atau pada pasien yang meminta. Belum ada dukungan psikiatri sebagai upaya deteksi dini dan tata laksana gangguan mental subklinis. Selain itu, belum banyak studi untuk mengetahui masalah mental terutama emosi pada remaja dengan LES dan bagaimana efek latihan kecakapan hidup. Oleh karena itu perlu dilakukan penelitian untuk mengetahui masalah emosi pada remaja perempuan dengan LES dan efektivitas pelatihan kecakapan hidup-modul pengelolaan emosi $(\mathrm{PKH}-$ MPE) untuk mengatasi masalah emosi pada remaja perempuan dengan LES.

\section{Metode \\ Desain dan Populasi}

Desain penelitian ini adalah uji klinis teracak tanpa blinding dan matching yang dilakukan di RSUPN dr. Cipto Mangunkusumo (RSCM), Jakarta pada tahun 2019. Subjek dalam penelitian ini adalah remaja perempuan dengan LES berusia 1018 tahun yang diambil secara konsekutif. Kriteria inklusi adalah remaja perempuan dengan aktivitas LES remisi total yang diukur dengan Systemic Lupus Erythematosus Disease Activity Index (SLEDAI) (SLEDAI=0) dan aktivitas penyakit ringan (SLEDAI=1-5). Sementara yang mengalami LES aktivitas sedang atau berat selama 3 bulan terakhir dan yang mengalami gangguan mental menurut skrining Mini-Kid (Interview Mini ICD-10 Psikiatri untuk anak dan remaja) tidak diikutsertakan dalam penelitian ini.

Subjek dijelaskan rencana penelitian, mengisi informed consent dan informed assent, kemudian dirandomisasi menjadi 2 kelompok: perlakuan dan kontrol. Jumlah subjek dihitung dengan rumus uji perbedaan dua proporsi dengan selisih nilai yang diharapkan 1,5. Berdasarkan perhitungan besar sampel dan antisipasi drop out, jumlah sampel 
yang dibutuhkan pada masing-masing kelompok adalah 15 orang.

\section{Instrumen Penelitian}

Instrumen penelitian berupa kuesioner yang berisi usia, riwayat neuropsikiatri lupus eritematosus sistemik (NPLES), penggunaan obat, dan lama menderita LES. Selain itu, digunakan kuesioner Strength and Difficult Questionnaire (SDQ) yang merupakan alat skrining masalah emosi dan perilaku pada anak dan remaja yang dikembangkan oleh Robert Goodman pada tahun 1997. Kuesioner SDQ sudah diterjemahkan dan divalidasi oleh Wiguna et al. ${ }^{8}$

SDQ merupakan kuesioner self-report yang terdiri atas 25 pertanyaan yang dikelompokkan menjadi lima komponen yakni masalah emosi, perilaku, hiperaktivitas, masalah dengan teman sebaya, dan perilaku prososial. Jawaban setiap pertanyaan dikuantifikasi menjadi 0 : tidak benar; 1 : agak benar; dan 2: benar. Nilai total SDQ diperoleh dari hasil penjumlahan semua komponen dengan interpretasi dinyatakan normal jika 0-16, ambang/ borderline jika 16-19, dan abnormal jika nilai 20-40. ${ }^{9}$

Masalah emosi dinilai dengan menganalisis lima pertanyaan menyangkut masalah emosi, yaitu: 1) keluhan fisik (sering mengeluh nyeri kepala, nyeri perut atau nyeri lainnya); 2) sering kuatir (sering tampak kuatir); 3) sering merasa tidak bahagia (sering merasa tidak bahagia, sedih atau menangis); 4) gugup (gugup atau sulit berpisah dengan orangtua/ pengasuh pada situasi baru, mudah kehilangan rasa percaya diri) dan 5) banyak ketakutan (banyak yang ditakuti, mudah takut). Nilai masalah emosi dibagi tiga kategori yakni normal (0-5), borderline (6) dan abnormal (7-10).

\section{Intervensi}

Intervensi pada kelompok perlakuan berupa Pelatihan Kecakapan Hidup, Modul Pengelolaan Emosi (PKH-MPE). Pelatihan kecakapan hidup berupa pertemuan kelompok dalam bentuk ceramah, diskusi, tanya jawab, bermain peran, dan aktivitas dalam kelompok. Pertemuan kelompok mengacu pada Modul Pelatihan Kecakapan Hidup Meningkatkan Kesehatan Jiwa Remaja yang diterbitkan oleh Direktorat Bina Pelayanan Kesehatan Jiwa, Dirjen Yanmed, Departemen Kesehatan Republik Indonesia tahun 2006. ${ }^{10}$
Kelompok kontrol dan perlakuan diminta mengisi kuesioner SDQ sebelum dan empat minggu setelah pelatihan. Pada masa observasi, tidak diberikan terapi atau pendampingan psikososial tambahan. Subjek tetap kontrol ke rumah sakit dan mendapatkan terapi dari dokter anak sesuai dengan kebutuhannya selama penelitian.

Setiap subjek dan orang tuanya sudah mendapat penjelasan tentang penelitian, mengisi informed consent dan informed assent tanpa paksaan. Subjek dapat menarik diri dari penelitian kapan saja. Penelitian ini telah lolos kaji etik pada tanggal 20 Mei 2019 dari Komite Etik Penelitian FKUI nomor KET.589/UN2.FI/ETIK/ PPM.00.02/2019.

\section{Analisis Statistik}

Data dianalisis dengan perangkat lunak Statistical Package for Sosial Sciences (SPSS) versi 20. Untuk analisis deskriptif digunakan perhitungan rerata, standar deviasi, nilai tengah, rentang, jumlah, dan persentase. Uji beda rerata dua kelompok tidak berpasangan menggunakan uji $\mathrm{t}$ jika distribusi data normal dan uji Mann Whitney jika distribusi data tidak normal. Perhitungan efektivitas menggunakan effect size dengan rumus Cohen's. Effect size 0,2-0,5 dinyatakan sebagai efektivitas kecil/rendah, 0,5-0,8 efek sedang, dan di atas 0,8 dinyatakan efektivitas besar/tinggi.

\section{Hasil}

Subjek penelitian ini berusia 10 sampai dengan 18 tahun, dengan rerata usia pada kelompok perlakuan adalah 14,1 tahun dan 14,5 tahun pada kelompok kontrol. Dari seluruh subjek di kelompok kontrol dan perlakukan, 22 orang memiliki aktivitas LES ringan dan sudah 2 tahun terdiagnosis LES. Terdapat 1 subjek dengan riwayat mengalami NPLES pada masing-masing kelompok (Tabel 1).

Pada awal studi terdapat 6 subjek yang menunjukan skor SDQ abnormal, yaitu 4 orang di kelompok perlakuan dan 2 orang kelompok kontrol. Terdapat 4 subjek dengan nilai SDQ borderline. Rerata nilai SDQ total pada kelompok perlakuan 13,2 (SD 6,3) dan pada kelompok kontrol 12,5 (SD 5,9); tidak terdapat perbedaan bermakna (uji t, $p=0,72$ ). Selain itu, tidak ada perbedaan bermakna (uji t, $p=0,16$ ) pada nilai masalah emosi di kedua kelompok yakni 5,1 (SD 1,8) pada kelompok perlakuan dan kelompok kontrol yakni 4 (SD 2,3). 
Tabel 1. Karakteristik Subjek pada Kelompok PKH-MPE dan Kontrol

\begin{tabular}{|c|c|c|}
\hline Karakteristik & Kelompok PKH-MPE & Kontrol \\
\hline Rerata Usia (SD), tahun & $14,1(2,7)$ & $14,5(2,6)$ \\
\hline \multicolumn{3}{|l|}{ Pendidikan } \\
\hline SD & 5 & 3 \\
\hline SMP & 3 & 4 \\
\hline SMA & 7 & 8 \\
\hline Lama Menderita LES (SD), tahun & $2,2(1,0)$ & $2,7(1,7)$ \\
\hline \multicolumn{3}{|l|}{ Aktivitas LES } \\
\hline Aktivitas Ringan & 12 & 10 \\
\hline Remisi Total & 3 & 5 \\
\hline \multicolumn{3}{|l|}{ Riwayat NPLES } \\
\hline $\mathrm{Ya}$ & $1(6,7)$ & $1(6,7)$ \\
\hline Tidak & $14(93,3)$ & $14(93,3)$ \\
\hline \multicolumn{3}{|l|}{ Dosis Penggunaan Obat per Hari (SD) } \\
\hline Immunosupresan (asam mikofulonat) (mg) & $600(188,4)$ & $475,71(167,1)$ \\
\hline Steroid (mg) & $8(2,6)$ & $8,8(6,6)$ \\
\hline Vitamin D (IU) & $1422,2(1124,5)$ & $657,1(320,7)$ \\
\hline \multicolumn{3}{|l|}{ Proporsi nilai SDQ total (\%) } \\
\hline Normal & $10(66,7)$ & $10(66,7)$ \\
\hline Borderline & $1(6,7)$ & $3(20)$ \\
\hline Abnormal & $4(26,7)$ & $2(13,7)$ \\
\hline
\end{tabular}

\section{Perbandingan Nilai SDQ Setelah Perlakuan}

Empat minggu setelah dilakukan pelatihan PKH-MPE padakelompok perlakukan, pemeriksaan SDQ dilakukan untuk kedua kelompok. Tidak terdapat subjek yang memiliki nilai SDQ abnormal. Sebanyak empat subjek memiliki nilai SDQ borderline (Tabel 2).
Terdapat perbaikan nilai SDQ hampir pada semua komponen, kecuali komponen hiperaktivitas dan komponen perilaku prososial pada kelompok perlakuan. Setelah mengikuti pelatihan PKH-MPE, pada kelompok perlakukan terdapat perbaikan yang bermakna pada masalah emosi $(p=0,002)$, masalah perilaku $(p=0,027)$, hiperaktivitas $(p=0,040)$ dan nilai SDQ total $(p=0,001)$.

Tabel 2. Nilai SDQ Sebelum dan Setelah PKH-MPE pada Kelompok Perlakuan dan Kontrol

\begin{tabular}{lcccccc}
\hline \multirow{2}{*}{ Nilai SDQ } & \multicolumn{3}{c}{ Perlakuan } & \multicolumn{3}{c}{ Kontrol } \\
\cline { 2 - 7 } & $\begin{array}{c}\text { Sebelum } \\
\text { Rerata (SD) }\end{array}$ & $\begin{array}{c}\text { Setelah } \\
\text { Rerata (SD) }\end{array}$ & $\mathbf{p}$ & $\begin{array}{c}\text { Sebelum } \\
\text { Rerata (SD) }\end{array}$ & $\begin{array}{c}\text { Setelah } \\
\text { Rerata (SD) }\end{array}$ & $\mathbf{p}$ \\
\hline SDQ total & $13,3(6,3)$ & $9,1(4,1)$ & $0,001^{\mathrm{a}}$ & $12,47(5,97)$ & $10,73(4,70)$ & $0,050^{\mathrm{a}}$ \\
Masalah emosi & $5,1(1,8)$ & $3,3(1,1)$ & $0,002^{\mathrm{b}}$ & $4,00(2,27)$ & $3,53(1,60)$ & $0,213^{\mathrm{b}}$ \\
Masalah perilaku & $2,7(2,0)$ & $1,7(1,1)$ & $0,027^{\mathrm{a}}$ & $2,73(1,79)$ & $2,40(1,59)$ & $0,313^{\mathrm{a}}$ \\
Perilaku hiperaktif & $3,0(1,7)$ & $2,3(1,8)$ & $0,040^{\mathrm{b}}$ & $3,00(2,14)$ & $3,27(1,75)$ & $0,836^{\mathrm{b}}$ \\
Masalah dengan teman sebaya & $2,5(1,8)$ & $1,8(1,3)$ & $0,143^{\mathrm{a}}$ & $2,53(1,81)$ & $1,53(1,55)$ & $0,011^{\mathrm{b}}$ \\
Perilaku prososial & $8,1(1,6)$ & $8,5(1,7)$ & $0,058^{\mathrm{b}}$ & $7,60(1,68)$ & $7,27(1,67)$ & $0,374^{\mathrm{b}}$ \\
\hline
\end{tabular}

aji t berpasangan; ${ }^{b}$ ji Wilcoxon

Pada penelitian ini juga membandingkan perubahan nilai SDQ yang merupakan selisih skor SDQ sebelum dan sesudah pelatihan pada kelompok perlakuan dan kelompok kontrol.
Terdapat perbedaan bermakna rerata perubahan nilai masalah emosi pada kedua kelompok 1,8 (SD $1,5)$ berbanding $0,5(S D 1,5)$ dengan nilai $p=0,025$ (Tabel 3). 
Tabel 3. Beda Rerata Kelompok Perlakuan dan Kontrol

\begin{tabular}{lccc}
\hline \multicolumn{1}{c}{ Beda Rerata } & Perlakuan & Kontrol & p \\
\hline Nilai SDQ total & Rerata (SD) & $1,7(3,1)$ & $0,074^{\mathrm{a}}$ \\
Nilai masalah emosi & $4,1(3,9)$ & $0,5(1,6)$ & $0,025^{\mathrm{a}}$ \\
Nilai masalah perilaku & $1,8(1,5)$ & $0,3(1,2)$ & $0,182^{\mathrm{a}}$ \\
Nilai perilaku hiperaktif & $1,1(1,7)$ & $-0,7(1,9)$ & $0,233^{\mathrm{b}}$ \\
Nilai masalah dengan teman sebaya & $0,7(1,1)$ & $1,0(1,3)$ & $0,486^{\mathrm{b}}$ \\
Nilai perilaku prososial & $0,7(1,8)$ & $0,3(1,3)$ & $0,061^{\mathrm{b}}$ \\
\hline
\end{tabular}

aUji t tidak berpasangan; ' $U j i$ Mann-Whitney

\section{Masalah Emosi pada Remaja Perempuan dengan LES}

Studi ini menemukan bahwa masalah emosi yang paling banyak ditemukan pada remaja perempuan dengan LES adalah banyaknya kekuatiran, yakni sebanyak 14 subjek $(46,67 \%)$ menjawab agak benar dan 10 subjek $(33,3 \%)$ menjawab benar. Pada kelompok yang mendapatkan PKH-MPE, masalah emosi yang paling banyak ditemukan adalah rasa gugup, sedangkan pada kelompok kontrol masalah emosi yang banyak ditemukan adalah banyaknya kekuatiran (Tabel 4).

Tabel 4. Frekuensi Masalah Emosi Sebelum Pelatihan

\begin{tabular}{lcccccc}
\hline \multirow{2}{*}{ Masalah Emosi } & \multicolumn{3}{c}{ Perlakuan } & \multicolumn{3}{c}{ Kontrol } \\
\cline { 2 - 7 } & $\begin{array}{c}\text { Tidak } \\
\text { benar }\end{array}$ & $\begin{array}{c}\text { Agak } \\
\text { benar }\end{array}$ & Benar & $\begin{array}{c}\text { Tidak } \\
\text { benar }\end{array}$ & Agak benar & Benar \\
\hline Keluhan fisik & 5 & 6 & 4 & 5 & 9 & 1 \\
Banyak kekuatiran & 3 & 5 & 7 & 3 & 9 & 3 \\
Sering tidak bahagia & 6 & 8 & 1 & 4 & 10 & 1 \\
Gugup & 1 & 7 & 7 & 6 & 5 & 4 \\
Banyak ketakutan & 5 & 5 & 5 & 4 & 9 & 2 \\
\hline
\end{tabular}

Dari perbandingan rerata masalah emosi yang dialami oleh subjek, pada kelompok yang mendapatkan PKH-MPE didapati perbaikan rerata masalah emosi pada pertanyaan adanya keluhan fisik $(p=0,021)$; banyak kekuatiran $(p=0,020)$ dan perasaan gugup $(p=0,020)$. Meskipun demikian, pada kelompok kontrol juga ditemukan perbaikan pada masalah emosi yakni banyak ketakutan $(p=0,014)$ (Tabel 5).

Tabel 5. Rerata Masalah Emosi Sebelum dan Sesudah Pelatihan

\begin{tabular}{lcccccc}
\hline \multicolumn{1}{c}{ Masalah emosi } & \multicolumn{3}{c}{ Perlakuan } & \multicolumn{3}{c}{ Kontrol } \\
\cline { 2 - 6 } & Sebelum & Setelah & $\mathbf{p}^{*}$ & Sebelum & Setelah & $\mathbf{p}^{*}$ \\
\hline Keluhan fisik & $0,9(0,8)$ & $0,3(0,5)$ & 0,021 & $0,7(0,6)$ & $0,7(0,6)$ & 1,000 \\
Banyak kekuatiran & $1,3(0,8)$ & $0,8(0,8)$ & 0,020 & $1,0(0,6)$ & $1,0(0,6)$ & 1,000 \\
Sering tidak bahagia & $0,7(0,6)$ & $0,5(0,5)$ & 0,180 & $0,8(0,6)$ & $0,7(0,7)$ & 0,564 \\
Gugup & $1,4(0,6)$ & $0,9(0,6)$ & 0,020 & $0,9(0,8)$ & $0,7(0,6)$ & 0,480 \\
Banyak ketakutan & $1,0(0,8)$ & $0,7(0,6)$ & 0,206 & $0,9(0,6)$ & $0,5(0,6)$ & 0,014 \\
\hline
\end{tabular}

* uji Wilcoxon

\section{Diskusi}

Pada penilaian awal ditemukan sebanyak 20 subjek penelitian $(66,7 \%)$ memiliki SDQ normal, 4 subjek $(13,3 \%)$ memiliki SDQ borderline dan 6 subjek (20\%) dengan SDQ abnormal. Masalah emosi dan perilaku yang terdapat pada anak dengan LES dan terdeteksi pada penilaian SDQ ini sesuai dengan penelitian lainnya yang menemukan adanya gangguan emosi pada anak dengan LES. Louthrenoo et $\mathrm{al}^{11}$ melaporkan prevalensi gangguan emosi pada anak dengan LES adalah $25 \%$.

Seluruh subjek pada penelitian ini memiliki karakteristik klinis yang serupa, yaitu penyakit remisi total dan aktivitas ringan. Subjek merupakan 
remaja perempuan dengan LES yang sudah mengalami LES selama sekitar 2 tahun.

Metode intervensi yang dilakukan dalam penelitian ini adalah pelatihan kecakapan hidup. Pelatihan kecakapan hidup adalah suatu pelatihan untuk meningkatkan kemampuan organisasi pola pikir sehingga menjadi rangkaian perilaku terintegrasi dan dapat diterima oleh lingkungan budaya setempat sehingga dapat meningkatkan hubungan antar manusia. Tujuan pelatihan kecakapan hidup adalah untuk meningkatkan keterampilan sosial dan pengetahuan untuk meningkatkan interaksi sosial dengan orang lain dan mencapai kompetensi sosial. Mengelola emosi adalah salah satu modul yang termasuk dalam pelatihan kecakapan hidup. Di Indonesia telah dikembangkan Modul Pelatihan Meningkatkan Kesehatan Jiwa Remaja di Sekolah Melalui Pendidikan Kecakapan Hidup yang dikeluarkan oleh Direktorat Bina Pelayanan Kesehatan Jiwa, DirJen Bina Yanmed, DepKes RI, 2006. ${ }^{10}$

Pada kelompok perlakuan, subjek mendapat pelatihan kecakapan hidup dengan topik pengelolaan emosi. Pelatihan diberikan dengan pendekatan kelompok dan bersifat interaktif. Pelatihan dalam kelompok kecil memungkinkan interaksi masing-masing subjek secara aktif sehingga lebih dapat menyampaikan pendapat serta perasaan yang dialami. Pelatihan dimulai dengan pengenalan LES, mulai dari etiologi, gejala, tata laksana, dan pencegahan. Selanjutnya diberikan pemahaman bagaimana hubungan penyakit dengan emosi pasien, dan bagaimana menghadapi emosi yang negatif. Masalah emosi yang paling banyak pada remaja perempuan dengan LES adalah banyak kekuatiran.

Empat minggu setelah pelatihan, dilakukan pengukuran SDQ pada kelompok perlakuan dan kelompok kontrol. Kelompok yang mendapat $\mathrm{PKH}-$ MPE terdapat perbaikan masalah emosi yang bermakna dan perbaikan nilai SDQ total, nilai pada masalah perilaku dan hiperaktivitas. Kelompok yang mendapatkan PKH-MPE mengalami perbaikan masalah emosi pada komponen keluhan fisik, banyak kekuatiran dan perasaan gugup. Hasil tersebut didukung oleh studi-studi sebelumnya yakni masalah emosi yang banyak ditemukan pada remaja dengan LES adalah depresi dan kecemasan. ${ }^{12,13}$

Pasien remaja dengan penyakit kronik, seperti remaja dengan LES, perlu mendapatkan perhatian pada penyakit fisiknya dan perhatian pada deteksi (preventif dan promotif) serta tata laksana masalah kesehatan jiwa yang dapat terjadi. Pendekatan yang dilakukan adalah dengan tata laksana penyakit fisik dan intervensi psikososial. Intervensi psikososial yang dapat dilakukan bagi pasien berusia remaja adalah dengan pelatihan kecakapan hidup, khususnya modul mengelola emosi.

Pelatihan kecakapan hidup dapat membantu anak dan remaja menghadapi beberapa aspek dalam kehidupan penderita penyakit kronik. Hemmatpoor et $\mathrm{al}^{14}$ melaporkan pelatihan kecakapan hidup dapat memperbaiki beberapa aspek kehidupan penderitan penyakit sklerosis multiple, seperti ketaatan dalam pengobatan dan perbaikan manajemen diri. Salah satu tema yang menjadi bagian dari pelatihan kecakapan hidup pada studi ini adalah manajemen emosi. ${ }^{14}$

Penelitian Rahmati et al $^{15}$ dan Shwetha ${ }^{16}$ juga mendapatkan perbaikan skor masalah emosi dan skor kekuatan mental setelah subjek menjalani pelatihan kecakapan hidup selama 10 minggu. Zhang et al ${ }^{17}$ melakukan meta-analisis dan mendapatkan bahwa terapi psikososial pada pasien LES tidak menunjukkan perbedaan tingkat kesehatan mental, namun terdapat penurunan secara bermakna untuk mengatasi gejala cemas, depresi, dan stres. ${ }^{17}$

Meta-analisis yang dilakukan Zhang et al ${ }^{17}$ menemukan pendekatan psikososial yang banyak dipilih adalah bentuk konseling, psikoterapi dan pelatihan psikoedukasional. Pendekatan ini banyak dipilih karena dapat memberikan informasi mengenai gejala dan tata laksana penyakit, juga membantu pasien memahami pengaruh masalah emosi yang terjadi, bagaimana hubungannya dengan kekambuhan penyakit serta pengaruh emosi pada aspek kehidupannya yang lain. ${ }^{17}$

Pendekatan berbentuk kelas juga memungkinkan interaksi sesama penderita LES yang dapat menumbuhkan perasaan tidak sendiri dalam menghadapi penyakitnya, sehingga memperbaiki masalah emosi. Bentuk terapi dalam kelompok sangat mungkin dilakukan, mudah dan membantu mencegah terjadinya masalah emosi yang lebih berat pada remaja dengan LES.

\section{Kesimpulan}

Pelatihan kecakapan hidup yang berfokus pada modul pengelolaan emosi dapat memperbaiki masalah emosi pada remaja perempuan dengan LES serta masalah emosi spesifik pada remaja dengan LES terutama keluhan fisik, cemas dan perasaan gugup. 


\section{Daftar Pustaka}

1. Tamirou F, Arnaud L, Talarico R, Scirè CA, Alexander T, Amoura Z, et al. Systemic lupus erythematosus: state of the art on clinical practice guidelines. RMD Open. 2018;4(2):1-6. doi: 10.1136/rmdopen-2018-000793

2. Golder V, Kandane-Rathnayake R, Hoi AY-B, Huq M, Louthrenoo W, An Y, et al. Association of the lupus low disease activity state (LLDAS) with health-related quality of life in a multinational prospective study. Arthritis Res Ther. 2017;19(1):1-11. doi: 10.1186/ s13075-017-1256-6

3. Rees F, Doherty M, Grainge MJ, Lanyon P, Zhang W. The worldwide incidence and prevalence of systemic lupus erythematosus: a systematic review of epidemiological studies. Rheumatology. 2017;56(11):1945-61. doi: 10.1093/rheumatology/kex260

4. Ambrose N, Morgan TA, Galloway J, lonnoau Y, Beresford MW, Isenberg DA. Differences in disease phenotype and severity in SLE across age groups. Lupus. 2016;25(14):1542-50. doi: 10.1177/0961203316644333

5. Batubara JR. Adolescent development (perkembangan remaja). Sari Pediatr. 2016;12(1):219. DOI: http://dx.doi.org/10.14238/sp12.1.2010

6. Thabrew H, McDowell H, Given K, Murrell K. Systematic review of screening instruments for psychosocial problems in children and adolescents with long-term physical conditions. Glob Pediatr Health. 2017;4: 2333794X17690314. doi: 10.1177/2333794X17690314.

7. Davis AM, Rubinstein TB, Rodriguez M, Knight AM. Mental health care for youth with rheumatologic diseases - bridging the gap. Pediatr Rheumatol Online J. 2017;15(1):85. doi: 10.1186/s12969-017-0214-9.

8. Wiguna T, Samuel P, Manengkei K, Pamela C, Rheza AM, Hapsari WA. Masalah emosi dan perilaku pada anak dan remaja di poliklinik jiwa anak dan remaja RSUPN dr. Ciptomangunkusumo (RSCM), Jakarta. Sari Pediatr. 2010;12:270-7.

9. Mieloo $\mathrm{CL}$, Bevaart F, Donker $\mathrm{MCH}$, van Oort FVA, Raat $\mathrm{H}$, Jansen $\mathrm{W}$. Validation of the SDQ in a multiethnic population of young children. Eur J Public Health. 2014;24(1):26-32. doi: 10.1093/eurpub/ckt100.
10. Departemen Kesehatan RI Direktorat Bina Pelayanan Kesehatan Jiwa. Modul pelatihan meningkatkan kesehatan jiwa remaja di sekolah melalui pendidikan kecakapan hidup (life skills education). Jakarta: Departemen Kesehatan Republik Indonesia; 2006.

11. Louthrenoo O, Krairojananan J, Chartapisak W, Opastirakul S. Psychosocial functioning of children with systemic lupus erythematosus. J Paediatr Child Health. 2012;48(12):1091-4. doi: 10.1111/j.14401754.2012.02499.x

12. Knight AM, Xie M, Mandell DS. Disparities in psychiatric diagnosis and treatment for youth with systemic lupus erythematosus: analysis of a National US Medicaid Sample. J Rheumatol. 2016;43(7):142733. doi: 10.3899/jrheum.150967

13. Knight A, Weiss $P$, Morales K, Gerdes M, Gutstein $A$, Vickery $M$, et al. Depression and anxiety and their association with healthcare utilization in pediatric lupus and mixed connective tissue disease patients: a cross-sectional study. Pediatr Rheumatol Online J. 2014;12:42. doi: 10.1186/1546-0096-12-42.

14. Hemmatpoor B, Gholami A, Parnian S, Seyedoshohadaee $M$. The effect of life skills training on the self-management of patients with multiple sclerosis. J Med Life. 2018;11(4):387-93. doi: 10.25122/jml-2018-0044.

15. Rahmati B, Adibrad N, Tahmasian K, Sedghpour BS. The effectiveness of life skill training on social adjustment in children. Procedia - Soc Behav Sci. 2010;5:870-4. https://doi.org/10.1016/j.sbspro.2010.07.201

16. Shwetha BC. The role of life skills training in developing emotional maturity and stress resilience among adolescents. Int J Indian Psychol. 2015;2(4):193-203.

17. Zhang J, Wei W, Wang CM. Effects of psychological interventions for patients with systemic lupus erythematosus: a systematic review and metaanalysis. Lupus. 2012;21(10):1077-87. doi: $10.1177 / 0961203312447667$ 